\title{
Precancerous Lesions of the Breast
}

\author{
Annette Lebeau \\ Department of Pathology, University Medical Center Hamburg-Eppendorf, Hamburg, \\ Pathology Group Practice, Lübeck, Germany
}

The introduction of mammography screening has caused an increased detection of precancerous lesions. Nowadays, ductal carcinoma in situ (DCIS) accounts for up to $25 \%$ of all newly diagnosed breast cancer cases in screening regions [1, 2]. Furthermore, mammography screening has attracted attention to a variety of early precursor lesions that have been observed before at most as an accompanying finding in the vicinity of invasive breast carcinomas. These include intraductal proliferative lesions with atypia like flat epithelial atypia (FEA) and atypical ductal hyperplasia $(\mathrm{ADH})$. The detection of these lesions in large core needle biopsies, used for the histological assessment of suspect mammographic lesions, especially microcalcifications, has brought about questions regarding their biological significance and practical management. They represent a broad spectrum of lesions with variable risk of progression. Nowadays it is not possible to identify with absolute certainty which of these lesions will progress and which not. The uncertainty how to handle them adequately is reflected in the histological classification used in mammography screening where these lesions are categorized as 'B3: lesions of uncertain malignant potential' [3].

Tailoring the treatment of precancerous lesions according to each individual case is a multidisciplinary challenge, which involves radiologists and pathologists as well as breast surgeons and, in case of DCIS, radio-oncologists and medical oncologists. There is a particular dilemma to balance the risk of causing unnecessary overtreatment or leaving an increased risk of recurrence or progression.

Therefore, this issue of BREAST CARE addresses the topic of precancerous lesions in a multidisciplinary approach. Experts from the involved disciplines give a summary of the current knowledge about the evolution, diagnosis, and management of precancerous lesions. The aim is to improve our understanding and handling of these heterogeneous lesions by bringing together the different perspectives.

The prevalence, radiological appearance and assessment procedure of those lesions categorized as B3 in percutaneous breast biopsies is addressed by Heywang-Köbrunner et al. [4].
B3 lesions represent $3-10 \%$ of the histologically assessed lesions in mammography screening. They comprise different histopathological entities which provide benign histology, but are either known to show heterogeneity or to have an increased (albeit low) risk of associated malignancy, e.g. FEA, $\mathrm{ADH}$, lobular neoplasia (LN), papillary lesions, radial scar, and phyllodes tumor. With regard to the differing cancer risk of these lesions, the authors demonstrate that many factors need to be considered to find an individually adapted recommendation for each patient. Avoidance of resecting too often and too much on the one hand, or resecting too seldom and too little on the other, requires an interdisciplinary team that takes into account and weighs all available information: biological risk, representative sampling, lesion size, and lesion extent, percentage of lesion removal, other individual risks and the possibility of surveillance.

But the biological and clinical significance of some of these lesions remains to be clarified. It is evident that the neoplastic process begins earlier than at the DCIS stage, but which histological lesions are directly involved in this process and what drives them in progression is not fully understood. Sinn et al. [5] give an illustrative review of those lesions that today are thought to represent the earliest neoplastic lesions that are related to the low-grade pathway of breast cancer development: FEA, ADH and LN. The presented molecular findings and clinical studies demonstrate that these lesions are both early precursor lesions and indicators for an increased ipsi- and contralateral cancer risk. However, the controversy and uncertainty about the biological significance of these lesions still remains. This is also reflected in the varying terminology used in the literature and the lack of generally accepted criteria that are highly reproducible [3, 6-9]. In consequence, the intraobeserver variability of these lesions is higher than in DCIS or invasive breast cancer. With account to these restrictions, Sinn et al. [5] summarize our current understanding of these lesions and add some advice for subtle management.

Since mammography screening has been implemented in many countries, DCIS has been given a great deal of atten-

\section{KARGER}

Fax +497614520714

Information@Karger.de

www.karger.com
(C) 2010 S. Karger GmbH, Freiburg

Accessible online at:

www.karger.com/brc
PD Dr. med. Annette Lebeau

Institut für Pathologie

Universitätsklinikum Hamburg-Eppendorf

Martinistr. 52, 20246 Hamburg, Germany

Tel. +49 40 7410-59244, Fax -56815

a.lebeau@uke.de 
tion. Appropriate treatment is crucial to prevent invasive breast cancer. But although nearly all conceivable combinations of surgery, radiotherapy and systemic treatments with anti-estrogens have been tested in different trials, the situation is still unsatisfactory. Important contributions are required from basic and clinical research to answer the most important questions [2]: Which DCIS is going to progress to invasive cancer and which will freeze in this stage? Which patient could be saved radiotherapy by complete excision of the disease? What are the criteria for complete excision in view of imaging and histologically assessed resection margins?

With respect to our currently limited ability to predict the biological behavior of DCIS, Kühn addresses the present handling of DCIS from the clinical perspective [10]. He sheds light on the effectiveness of surgery and the unfavorable therapeutic index of adjuvant treatment in the management of DCIS compared to invasive breast cancer. Although radiotherapy significantly reduces ipsilateral breast recurrences in unselected patients with DCIS, it has no effect on the already excellent overall survival of these patients. There is also no survival benefit from systemic anti-estrogen treatment with tamoxifen. Kühn gives a summary of the evidence that certain DCIS could be cured by complete surgical excision only. It is our current understanding, that DCIS is a localized process that is unicentric in most of the cases with a segmental distension within the ducts and lobules [11]. Consequently, Kühn emphasizes the need to evaluate a morphology-based treatment model that allows a complete resection of specified DCIS lesions without further adjuvant treatment.

Nevertheless, a more precise understanding of the biological behavior of the different subtypes of DCIS is needed to detect the decisive molecular mechanisms of tumor invasion and to identify those patients who are at risk of tumor progression. Cunha et al. [12] give a comprehensive overview of our current knowledge of the biological mechanisms of progression of DCIS. Additionally, systemic therapeutic approaches that interact with well-established tumor promoting pathways and recommended standards for reporting of DCIS are presented. The authors point out that morphological classifications go some way to predicting prognosis, but more sophisticated approaches are required to better tailor therapy to the individual. These approaches have to take into account not only molecular changes in the tumor cells, but also in the host microenvironment that provides a complex milieu of cellular and noncellular components that interact with the neoplastic epithelial cells and modulate key cellular functions such as growth, differentiation, angiogenesis and invasion. The markers with the most promising clinical potential are reviewed in the article. Since a number of studies did not find significant differences in genetic alterations or gene expression profiles between the tumor cells of DCIS and invasive carcinomas so far [13-19], the authors also focus on the potential role of microenvironment to better understand the transition from DCIS to invasive breast cancer. Further knowledge in this field will hopefully provide improved prognostic and predictive factors and will offer novel therapeutic opportunities to promote individualized treatment in patients with DCIS.

It is my hope that the readers of BREAST CARE find the selection of articles featured in this issue as instructive and stimulating as I do. I enjoyed reading and editing the articles and would like to express my sincere thanks to the authors who made this focus possible by contributing their valuable time and expertise.

\section{References}

1 Ernster VL, Ballard-Barbash R, Barlow WE, Zheng Y, Weaver DL, Cutter G, Yankaskas BC, Rosenberg R, Carney PA, Kerlikowske K, Taplin SH, Urban N, Geller BM: Detection of ductal carcinoma in situ in women undergoing screening mammography. J Natl Cancer Inst 2002; 94:1546-1554.

2 Aberle DR, Allegra CJ, Ganschow P, Hahn SM, Lee CN, Millon-Underwood S, Pike MC, Reed SD, Saftlas AF, Scarvalone SA, Schwartz AM, Slomski C, Yothers G, Zon R: NIH State-of-the-Science Conference Statement: Diagnosis and Management of Ductal Carcinoma In Situ (DCIS). NIH Consens State Sci Statements 2009;26:1-27.

3 Amendoeira I, Apostolikas N, Bellocq JP, Bianchi S, Boecker W, Borisch B, Bussolati G, Connolly CE, Cserni G, Decker T, Dervan P, Drijkoningen M, Ellis IO, Elston CW, Eusebi V, Faverly D, Heikkila P, Holland R, Kerner H, Kulka J, Jacquemier J, Lacerda M, Martinez-Penuela J, De Miguel C, Nordgren H, Peterse JL, Rank F, Regitnig P, Reiner A, Sapino A, Sigal-Zafrani B, Tanous AM, Thorstenson S, Zozaya E, Wells CA: Quality assurance guidelines for pathology: Cytological and histological non-operative procedures.
In Perry N, Broeders M, de Wolf C, Toernberg S, Holland R, von Karsa L (eds): European guidelines for quality assurance in breast cancer screening and diagnosis. Luxembourg, Office for Official Publications of the European Communities, 2006, pp 221-255.

4 Heywang-Köbrunner SH, Nährig J, Hacker A, Sedlacek S, Höfler H: B3 lesions: radiological assessment and multi-disciplinary aspects. Breast Care 2010;5:209-217.

5 Sinn HP, Elsewaf Z, Helmchen B, Aulmann S: Early breast cancer precursor lesions: lessons learned from molecular and clinical studies. Breast Care 2010;5:218-226.

6 Tavassoli FA, Eusebi V: Tumors of the Mammary Gland. Washington, DC, American Registry of Pathology, 2009.

7 Tavassoli FA, Devilee P (eds): World Health Organization Classification of Tumours. Pathology and Genetics of Tumours of the Breast and Female Genital Organs. in Lyon, IARC Press, 2003.

8 Amendoeira I, Apostolikas N, Bellocq JP, Bianchi S, Boecker W, Borisch B, Bussolati G, Connolly CE, Cserni G, Decker T, Dervan P, Drijkoningen M, Ellis IO, Elston CW, Eusebi V, Faverly
D, Heikkila P, Holland R, Kerner H, Kulka J, Jacquemier J, Lacerda M, Martinez-Penuela J, De Miguel C, Nordgren H, Peterse JL, Rank F, Regitnig P, Reiner A, Sapino A, Sigal-Zafrani B, Tanous AM, Thorstenson S, Zozaya E, Wells CA: Quality assurance guidelines for pathology: Open biopsy and resection specimens; in Perry N, Broeders M, de Wolf C, Toernberg S, Holland R, von Karsa L (eds): European guidelines for quality assurance in breast cancer screening and diagnosis. Luxembourg, Office for Official Publications of the European Communities, 2006, pp 256-311.

9 Schnitt SJ, Vincent-Salomon A: Columnar cell lesions of the breast. Adv Anat Pathol 2003;10:113-124.

10 Kühn T: Ductal carcinoma in situ: the clinical perspective. Breast Care 2010;5:227-232.

11 Faverly DR, Burgers L, Bult P, Holland R: Three dimensional imaging of mammary ductal carcinoma in situ: clinical implications. Semin Diagn Pathol 1994;11:193-198.

12 Cunha POR, Ornstein M, Jones JL: Progression of ductal carcinoma in situ from the pathological perspective. Breast Care 2010;5:233-239. 
13 Burkhardt L, Grob TJ, Hermann I, Burandt E, Choschzick M, Janicke F, Muller V, Bokemeyer C, Simon R, Sauter G, Wilczak W, Lebeau A: Gene amplification in ductal carcinoma in situ of the breast. Breast Cancer Res Treat 2009; DOI 10.1007/s10549-009-0675-8.

14 Lakhani SR: The transition from hyperplasia to invasive carcinoma of the breast. J Pathol 1999;187:272-278.

15 Ma XJ, Salunga R, Tuggle JT, Gaudet J, Enright E, McQuary P, Payette T, Pistone M, Stecker K, Zhang BM, Zhou YX, Varnholt H, Smith B, Gadd M, Chatfield E, Kessler J, Baer TM, Erlander MG Sgroi DC: Gene expression profiles of human breast cancer progression. Proc Natl Acad Sci U S A 2003;100:5974-5979.

16 Porter D, Lahti-Domenici J, Keshaviah A, Bae YK, Argani P, Marks J, Richardson A, Cooper A, Strausberg R, Riggins GJ, Schnitt S, Gabrielson E, Gelman R, Polyak K: Molecular markers in ductal carcinoma in situ of the breast. Mol Cancer Res 2003;1:362-375

17 Stratton MR, Collins N, Lakhani SR, Sloane JP Loss of heterozygosity in ductal carcinoma in situ of the breast. J Pathol 1995;175:195-201.

18 Dietrich D, Schuster M, Lesche R, Haedicke W, Kristiansen G: [Multiplexed methylation analysis-a new technology to analyse the methylation pattern of laser microdissected cells of normal breast tissue, DCIS and invasive ductal carcinoma of the breast]. Verh Dtsch Ges Pathol 2007;91:197-207.

19 van der Groep P, van Diest PJ, Menko FH, Bart J, de Vries EG, van der Wall E: Molecular profile of ductal carcinoma in situ of the breast in BRCA1 and BRCA2 germline mutation carriers. J Clin Pathol 2009;62:926-930. 